\title{
Initial effects of quinclorac on the survival and growth of high biomass tree species
}

\author{
J.P. Adams, M.H. Pelkki, V.L. Ford, A. Humphrey
}

Adams J.P., Pelkki M.H., Ford V.L., Humphrey A., 2017. Initial effects of quinclorac on the survival and growth of high biomass tree species. Ann. For. Res. 60(1): 75-87.

Abstract. Increasingly, short rotation woody crops are being planted for biofuel/biomass production on unused lands or marginal agricultural lands. Many of these plantations occur near agriculture land which is intensively managed including yearly herbicide applications. Herbicide drift from these applications may cause tree stress and decreasing yields impacting potential biomass production. Quinclorac, a rice herbicide, is often cited as a potential source of tree damage and is the focal herbicide of this study. Five planting stocks, including three eastern cottonwood clones, a hybrid poplar clone, and American sycamore, were assessed for herbicide affects and deployed at three sites across south Arkansas. Stocks were exposed to a full rate labeled for rice $\left(3.175 \mathrm{~L} \mathrm{ha}^{-1}\right)$, two rates simulating drift $(1 / 100$ th and $1 / 10$ th the full rate), and a no-spray control. Survival of all Populus clones decreased drastically as quinclorac rate increased, while there was little observed effect on American sycamore. Some variability in treatment response among poplars occurred below the full herbicide rate; however, direct spraying a full herbicide rate on poplars resulted in survival rates below 65 percent and negative growth rates due to dieback. Conversely, photosynthetic rates of remaining leaves increased as quinclorac rate increased. Survival and damage scores of American sycamore, regardless of herbicide rate, remained nearly constant. Keywords high-biomass species, herbicide drift, poplar, sycamore

Authors. Joshua P. Adams (adamsj@1atech.edu) - School of Agricultural Sciences and Forestry, Louisiana Tech University 1501 Reese Dr., Ruston, LA 71272, USA; Matthew H. Pelkki, Allan Humphrey - School of Forestry and Natural Resources, University of Arkansas at Monticello 110 University Court, Monticello, Arkansas 71656, USA; Victor L. Ford - Southwest Research and Extension Center, University of Arkansas Division of Agriculture 362 Highway 174 North, Hope, AR 71801, USA.

Manuscript received October 12, 2016; revised January 24, 2017; accepted January 31, 2017; online first February 08, 2017. 


\section{Introduction}

Increasingly throughout the world, multiple use landscapes and forest fragmentation has led to forest species facing new sets of challenges brought on by their recent exposures to anthropogenic environment alterations. This is especially true in areas experiencing forest transitions such as afforestation occurring through field abandonment and natural reestablishment or artificial plantings (Rudel et al. 2005). Fragmentation, such as that occurring in the Amazon, also has been shown to increase mortality in large trees simply by the rapid shift of the landscape (Laurance et al. 2000). This can be compounded by the use of herbicides interspersed with the forests in which evidence of direct negative impacts on both plant and wildlife species in landscapes across North America and Europe (Freemark \& Boutin 1995). This is especially the case in high-intensity agriculture areas with marginal lands scattered across the landscape in forests. Specifically in the Lower Mississippi Alluvial Valley (LMAV) in the US, have occurred over the last few decades on marginal agriculture lands and interest continues to increase with potential emerging market needs for biomass production (Dosskey et al. 2012). Biomass production using short rotation woody crops (SRWC) was first conceptualized in the 1960s (Brown 1976) and, as the demand for alternate energy increased, the U.S. Department of Energy (DOE) began to promote the research of biofuels from forest species. Several tree genre continue to be explored for energy sources including pines (Pinus), willow (Salix), poplar (Populus), sycamore (Platanus), and sweetgum (Liquidambar) (Dosskey et al. 2012; Johnson et al. 2007).

In many afforested areas, various Populus species and American sycamore (Platanus occidentalis) have held promise as SRWC because they historically occurred on many sites that could be afforested and potentially could reach or exceed 11.2 $\mathrm{Mg} \mathrm{ha}^{-1} \mathrm{yr}^{-1}$, the minimum level suggested by Graham (1994) for suitable bioenergy production. Eastern cottonwood is a short lived species often surviving for less than 80 years but is one of the fastest native hardwood trees in North America. The species inhabits sites that are seasonally flooded common to mesic, nutrient-rich bottomlands. The species ranges from throughout most of the continent east of the continental divide and the dioecious trees reproduce prolifically through wind-blown seed and vegetative propagation. (Dickmann et al. 2001). Eastern cottonwood has been extensively bred with many other species from the very broad genus to produce a large spectrum of hybrids. In the north half of the southeastern region of the United States, the Interamerican Poplar (Populus trichocarpa $\mathrm{x}$ deltiodes) has been one of the most successful for implementation into hardwood plantations. The hybrid maintains many of the wood traits of eastern cottonwood with increased productivity (Kline \& Coleman 2010). Taking advantage of hybrid vigor, clones of various crosses can be deployed on a wide range of sites while keeping high growth rates. One major impediment of using Populus hybrids is their susceptibility to Septoria leaf spot and stem canker (Septoria musiva Peck.)(Newcombe \& Ostry 2001, Rousseau et al. 2013).

American sycamore is also a common, fast growing species ranging through the eastern half of the United States generally along riparian areas. It is most common and has best growth potential on alluvial soils in bottomlands, specifically sandy loams or loams that are well drained. American sycamore is monoecious with fruits ripening by September and disseminated by the wind. Similar to the Populus species, sycamore can coppice from stumps but cuttings from mature trees generally will not root (Merz 1965).

To meet the minimum level of production suggested by Graham (1994), Eastern cottonwood and various derived hybrids have been assessed and bred for decades for rapid growth. Under natural conditions alone, cottonwoods can grow 1.5 meters in height and 2.5 cen- 
timeters in diameter annually (Taylor 2001). Indeed, Populus is perhaps the most heavily researched SRWC taxa and is a widely used SRWC because of its geographic adaptability, fast growth, and ease of reproduction (Zamora et al. 2015), though productivity decreases substantially after 4-8 years, which would be toward the end of a rotation for a SRWC (Kline \& Coleman 2010). On the other hand, a species such American sycamore has many similar traits but lacks the prolific coppice potential. Still, American sycamore does not generally grow as fast as various Populus species, with rates reported in the 4-6 $\mathrm{Mg} \mathrm{ha}^{-1} \mathrm{yr}^{-1}$ range (Davis \& Trettin 2006). However, they may surpass the $11.2 \mathrm{Mg} \mathrm{ha}^{-1} \mathrm{yr}^{-1}$ average rotation growth rate under intensive management (i.e., irrigation and fertilizer) with Steinbeck (1999) reporting rates as high as $12.5 \mathrm{Mg} \mathrm{ha}^{-1} \mathrm{yr}^{-1}$ over a five year rotation.

Over the landscape that may include afforested sites, especially in the LMAV, agricultural crops dominate the area and their intensive management practices can have great influence on the smaller scaled forested areas. One particular problem is the establishment of forests near agricultural land influenced by intense chemical applications. Norsworthy et al. (2007) stated that 50 percent of Arkansas rice consultants preferred using herbicides propanil and quinclorac as a post-emergent herbicide for grassy and broadleaf weeds in rice fields and 32 percent of rice consultants recommended three or more applications in a growing season. Quinclorac is a selective auxin herbicide often used over rice, canola, barley, sorghum and pasture fields for the control of dicot weeds and some grass weeds with susceptible plants (Fipke \& Vidal 2016). After the herbicide is sprayed, absorption occurs both through the leaves and through the roots with acropetal translocation through the plant (Williams et al. 2004). Symptoms usually occur between the seventh and tenth days after spraying and include chlorosis, leaf epinasty, and eventual necrosis thought to be specifically caused by cyanide production (Grossmann 2010). This production corresponds as well with ethylene growth inhibitor increases and recent evident supports the very selective resistance to this herbicide is due to inhibition of the ethylene biosynthesis pathway (Xu et al. 2013). When the herbicide is sprayed, it is absorbed by both leaves and through the roots with acropetal translocation through the plant (Williams et al. 2004). These uses extent the potential for high-biomass tree species to be exposed herbicide drift far beyond the confines of rice fields alone. This intensive spraying, often conducted aerially, can easily lead to chemical drift that occurs when chemical droplets are carried by the wind to non-target areas, such as forests (Miller \& Stoughton 2000). Thus, the purpose of the study was to assess growth and development of Populus clones and American sycamore respond to various rates of quinclorac.

\section{Material and methods}

\section{Site locations and descriptions}

This study was conducted on three sites located across south Arkansas: Hope, Monticello, and Rohwer. The Hope site was on the Southeast Research and Extension Center (33 ${ }^{\circ} 43^{\prime}$ 9.76", $\left.-93^{\circ} 31^{\prime} 49.92^{\prime \prime}\right)$ and was composed of Una silty clay loam. The Monticello site was on the University of Arkansas at Monticello School Forest (33 37' 12.31', $\left.-91^{\circ} 44^{\prime} 0.38^{\prime \prime}\right)$. The soils on this site was Henry silt loams. The Rohwer site (3347'35.47', -91' $17^{\circ}$ ' 10.94') was composed of Sharkey and Desha clays. Both the Hope and Monticello sites were note optimal sites for these species but served as a treatment nursery for herbicide rate evaluation. All three sites had site-preparation for planting including competition control and tillage in late February after initial greening of vegetation was beginning. Specifically, the Hope site was burned and disked prior to planting. The Rohwer site received an application of 4 percent glyphosate. The Monticello site was mowed and 5 percent glyphosate was applied 
to reemerging vegetation. After planting manual weeding was periodically conducted for competition control.

\section{Plant stock descriptions and study layout}

Five stock types were included in this study including three clones of eastern cottonwood (ST-66, S7C20 and Arborgen's ARB229) and an Arborgen clone of hybrid poplar (ARB188 trichocarpa $\mathrm{x}$ deltoides) [henceforth these four clones are collectively termed poplars] and woods run American sycamore. Cuttings from ST-66 and S7C20 were harvested during dormancy in the winter months of 2013 and early spring of 2014 from a stool bed near Mississippi State University campus in Starkville, MS. The Arborgen poplar cuttings were harvested in a similar manner from their Bellville, GA nursery. Sycamore bareroot 1-0 seedlings were lifted and bagged from a nursery in Lexington, SC. All seedlings/cuttings were shipped to Monticello, AR overnight after they were harvested. They were stored in a $4^{\circ} \mathrm{C}$ walk-in cooler until planting. Planting dates were March 25, 2014 at Hope, AR, March 29, 2014 at Monticello, AR, and March 31, 2014 at Rowher, AR. The study was designed in the fashion of a progeny trial with trees planted in two-tree plots by hand in 1.8 $\mathrm{m} \times 1.2 \mathrm{~m}$ spacing in a randomized split-plot design in which the site was split into the four herbicide treatment strips (main plot) and five stock types (subplots) were randomly assigned within the main plot with replications. There were 10 two-tree subplots for each stock type within each herbicide treatment at the Rowher and Hope sites and there were 8 two-tree subplots for each stock type within each herbicide treatment at the Monticello site. Between treatments (i.e., main plots), two buffer rows of trees were planted. Also, a buffer of two rows surrounding the entire study area was planted to reduce edge effect on growth due to increased resources and reduced competition.

\section{Herbicide treatment}

Quinclorac, in the form of Facet ${ }^{\circledR}$ L (BASF Corp., Research Triangle, NC, USA), was applied as herbicide treatments to coincide with the usual timing of quinclorac rice application (June $16^{\text {th }}-23^{\text {rd }}, 2014$ ). A banded herbicides were applied using $\mathrm{CO}_{2}$ powered backpack sprayers during a time when wind speeds less than $3 \mathrm{mph}$ and temperatures less than $85^{\circ} \mathrm{F}$ $\left(29.4^{\circ} \mathrm{C}\right)$. The herbicide treatments, representing the main plots, included an untreated check in which no herbicide was applied and a full rate which was the maximum labeled concentration for rice at $3.175 \mathrm{~L} /$ hectare. Two rates were also applied to mimic levels of drift including a $1 / 100^{\text {th }}$ rate $(0.03175 \mathrm{~L} /$ hectare $)$ and a $1 / 10^{\text {th }}$ rate $(0.3175 \mathrm{~L} /$ hectare $)$.

\section{Plant measurements}

Total tree height and dominant shoot height from the original cutting were measured for Platanus seedlings and Populus cuttings, respectively. Ground-line diameter (Platanus)/ dominant shoot diameter (Populus) measurements were also taken on each tree immediately prior to spraying and at 90 days after quinclorac application. Survival and ocular damage scores were taken immediately prior to herbicide application and 30,60 and 90 days after application. Ocular scoring was conducted based on a modification of scoring outlined by Meilan et al. (2000) and detailed in in Table 1. Each location's homogeneity across treatment and planting stock was assessed by measuring the border rows composed of a single check clone surrounding the entire study and each treatment. Height and diameter were regressed on row and column spatial locations. There were no significant effect of either row or column for height ( $p=0.85$ and $p=0.08$, respectively) and diameter ( $p=0.79$ and $p=$ 0.54 , respectively) before treatment application. This procedure affirmed that any differences among the experimental units were not an artifact of within site systematic bias. 
Table 1 Damage score was assigned to each tree based on the damage as assessed at each site across treatments and stock types by one trained individual at pre-application and 30-d, 60-d, and 90-d post-application.

\begin{tabular}{ll}
\hline Score & Damage description \\
\hline 0 & No damage \\
\hline 1 & Some leaf chlorosis, no apical damage \\
\hline 2 & Necrosis or discoloring in apical region, some leaf cupping \\
\hline 3 & Some top dieback and leaf discoloration and deformation \\
\hline 4 & Entire tree substantially damaged \\
\hline 5 & Death; no green foliage present \\
\hline
\end{tabular}

\section{Survival, damage, and growth analysis}

The study was analyzed as a split-plot completely randomized design. The experimental unit was each two tree plot replicated and randomized within each main plot herbicide treatment. Mean height change, diameter change, and damage scores were used in the analysis to determine herbicide and stock effects. Damage scores were analyzed as a repeated measure because observations were taken at three post-treatment time periods. Treatment and planting stock effects on survival, height and diameter were analyzed with an analysis of variance (ANOVA) via a general linear model (PROC GLM) in SAS software (SAS institute Inc., Cary, NC). Interactions in repeated measures analysis were further analyzed for each measured attribute using an ANCOVA technique in which the arcsine transformed damage score was regressed on herbicide treatment and slopes among time and stock type were treated as co-variants. Fisher's Least Significant Difference (LSD) means separation was used to identify differences among herbicide treatments and stock types.

\section{Physiological sampling and analysis}

At $60-d$ post-herbicide treatment, physiological changes among treatments and stocks were assessed on the Monticello site with a LICOR6400XT with a controlled Red/Blue LED light source chamber (LICOR; Lincoln, NE). One tree representing each stock in each treatment was selected for this analysis to minimize diurnal physiological variability due to the changing environment during the day. A mature leaf without necrosis was used to ensure the entire area of the measurement chamber was filled by living leaf tissue during measurement. The selected leaf was also required to be a fully formed leaf closest to the apex of the tree. All sampling was conducted during a clear day and was finished within 1h 30m (9:50 AM till 11:20 AM) after commencement with ambient temperatures ranging $5.05^{\circ} \mathrm{C}$ across this timeframe. The closed light source allowed for control of light exposure to the leaf during the measurement; while, the clear day ensured that the leaves were already acclimated to the approximate light intensity and not varying greatly due to cloud cover prior to measurement. LICOR6400XT settings included: reference $\mathrm{CO}_{2}=400 \mu \mathrm{mol} \mathrm{CO} \mathrm{mol}^{-1}$, air flow $=500$ $\mu \mathrm{mol} \mathrm{s}{ }^{-1}$, and LED light intensity $=1000 \mu \mathrm{mol}$ $\mathrm{m}^{-2} \mathrm{~s}^{-1}$. LED light intensity was set to this level based on average solar intensities from the previous day at the same sampling time. Reference $\mathrm{CO}_{2}$ was selected based on the average ambient global value. The leaf was clamped with the sensor head and allowed to equilibrate under the prescribed environmental settings until the unit's internal graphs indicated physiological variables had reached equilibrium (i.e., there was no upward or downward trend in the data). After equilibrium was reached in the leaf chamber, the data were logged. A total of 26 samples were logged where each sample was a leaf from a different tree.

Analysis of data were conducted using SAS software. Net photosynthesis $\left(\mu \mathrm{mol} \mathrm{CO}_{2} \mathrm{~m}^{-2}\right.$ 
$\left.\mathrm{s}^{-1}\right)$ was the response variable with planting stock and herbicide rate as predictor variables in a GLM. Because the sample size was limited to one individual from each stock in each treatment due to the limited time frame for sampling, interaction of plant stock and herbicide treatment was tested using Tukey's single degree-of-freedom for non-additively as described and implemented by Milliken and Johnson (1989) because of the small sample size. Briefly, this method allows for testing of the interaction with use of a single degree of freedom and then testing of the single factors with the remaining degrees of freedom. The data were further compared to ocular damage scores at $60-\mathrm{d}$ and total height and GLD change across the total 90-day testing period.

\section{Results}

Plant survival and damage effects from herbicide treatment

Prior to herbicide application, there was 97 percent survival of rooted and planted trees. Survival did decrease as expected through the course of the study, though final survival still remained over 50 percent across sites. Location did have a significant effect on survival $(p<0.01)$ with all sites significantly different from each other. Hope had the lowest survival at 55.3 percent, followed by Monticello at 65.5 percent, and Rowher with the best survival at 98.5 percent. In addition to an effect by location, the interaction of stock and treatment also significantly affected survival $(p<0.01)$.

Among the five stock types, American sycamore exhibited the best survival over the 90 day test with 97.5 percent survival that was unreactive to the treatments. The two Stoneville poplar clones ST-66 and S7C20 had the lowest survival with 60.1 percent and 53.6 percent survival respectively (Figure 1). ST66 expressed a unique pattern in regards to reaction to treatment. Plants in the control treatment performed worse than any of the herbicide treatments with the lowest survival. On the other hand the other three poplar clones showed a consistent decrease in survival as the herbicide rate increased. While the trend across poplar clones (excluding the control of ST-66) did show a decrease in survival percentage as herbicide increased, the difference

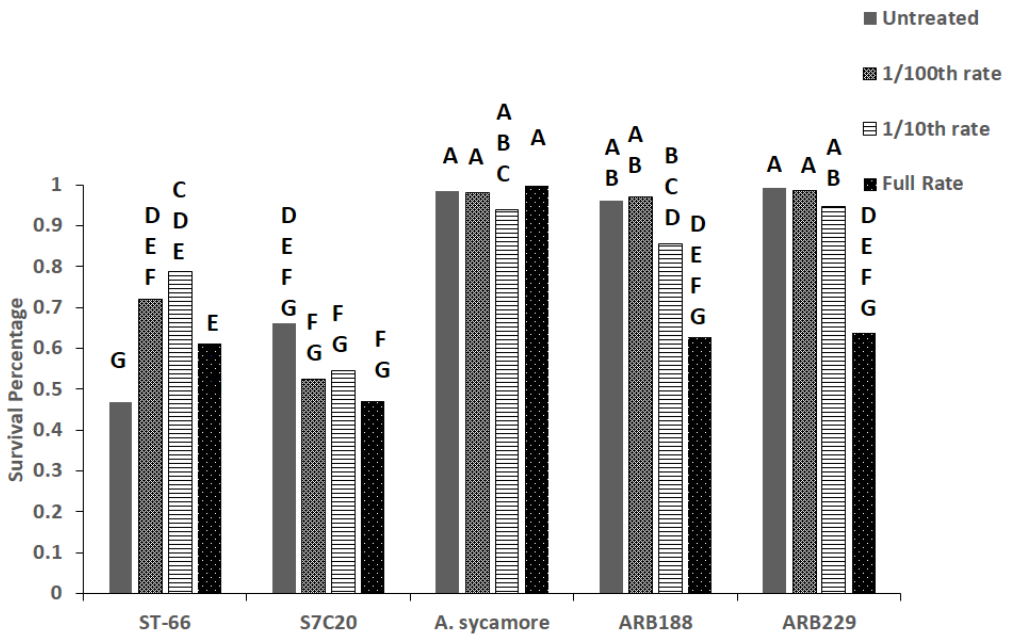

Figure 1 Survival percentage of five planting stocks under four herbicide treatments. Columns with differing letters above indicate significant differences in survival percentage across stock-by-treatment using least squares mean $(\alpha=0.05)$. 
was often not significant (e.g., ST-66 and S7C20) or was only significant between the full rate and the control and $1 / 100^{\text {th }}$ rate (e.g., ARB188).

Decreases in survival corresponded with increases in damage scores over time. All stock types exhibited a positive trend as damage increased with herbicide rate. Indeed, damage scores were affected $(p<0.01)$ by a stock type-by-herbicide interaction over time (i.e., over the three observation periods). American sycamore was the best performer across all three observations (Figure 2a-c). Across herbicide treatments over the three sampling periods, damage rating averaged 0.69 for American sycamore and only had a maximum rating of 1.4. This trend was evident as early as 30-days (Figure 2a), was virtually unchanged at 60-days (Figure 2b), and continued through 90-days (Figure 2c). Further analysis of data using a repeated measures structure resulted in the time component not having a significant effect across stock type and treatment ( $p>0.2$ or higher for time effect in all trend analyses). This demonstrates that negative plant effects from the herbicide appear soon after exposure and

\section{Figure 2}

Repeated damage assessments of five planting stocks at (A) 30, (B) 60, and (C) 90 days after herbicide treatment. (D) Transformed damaged scores were regressed across herbicide treatment by stock type, untransformed and graphed.

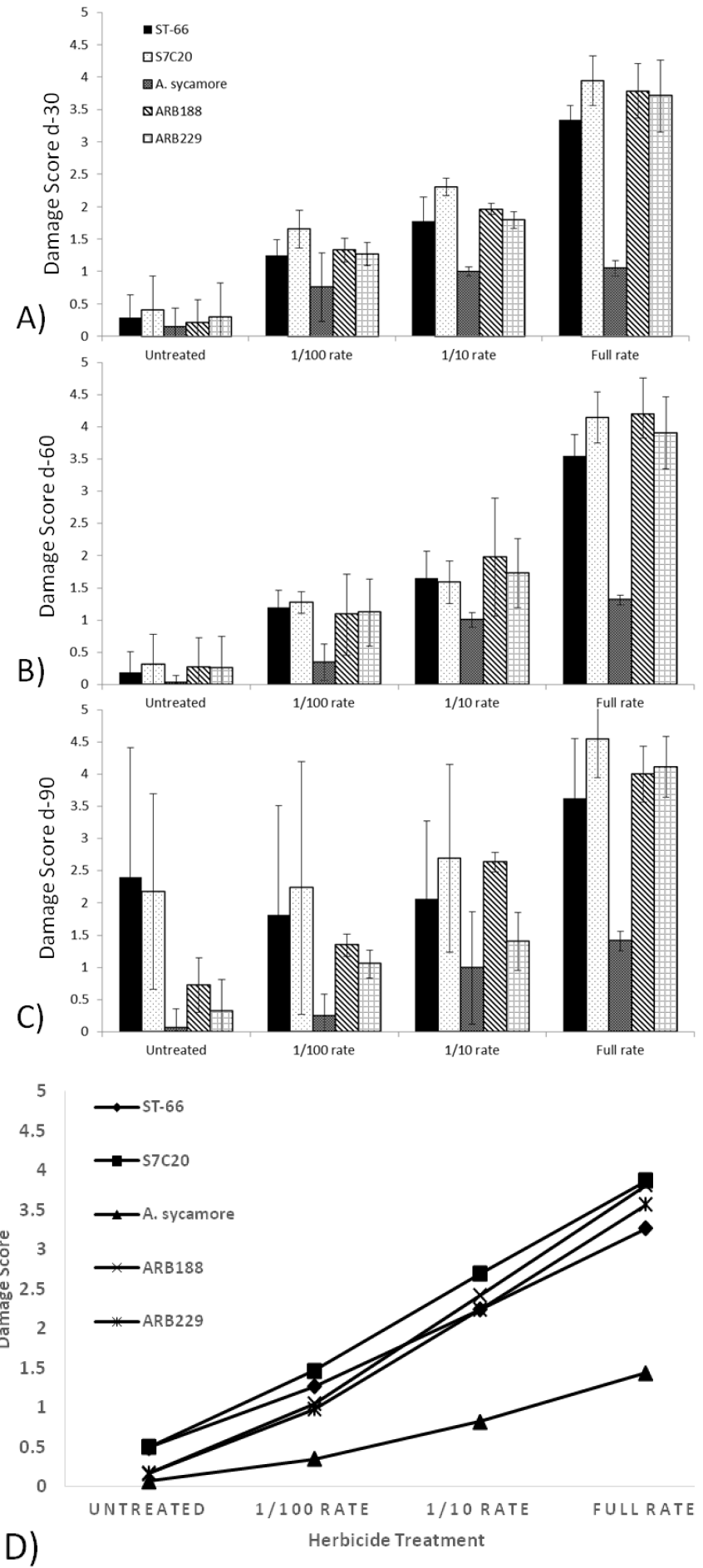


effects persist. Thus when the time effect is removed, the American sycamore remained nearly unchanged in damage score across herbicide treatment with a slope of 0.149 across treatment while all the poplars had slopes of 0.2 or greater across treatments (Figure $2 \mathrm{~d}$ ). The clones ST-66 and S7C20 had more stable slopes but this was not due to better damage scores at the greater herbicide rate treatments; rather, these two clones has poor scores at both untreated and $1 / 100^{\text {th }}$ rate herbicide treatments.

\section{Plant growth effects from herbicide treat- ment}

Before application of herbicide treatments, there were no significant effects of treatment or its interaction within stock type on height
( $p$-value $=0.48$ and 0.56 , respectively $)$ and diameter ( $p$-value $=0.08$ and 0.62 , respectively) of the trees. However, for both traits there were significant effects across stock types ( $p$-values $<0.01$ ). Stock type was expected to be different as cuttings were harvested from ortets of various sizes and American sycamores was planted as a bareroot seedling. Because of these pre-treatment measurement differences solely due to stock type, plant growth analysis was conducted on dimensional change from measurements at initial treatment until completion of the study after 90 days.

After 90 days post-herbicide treatment, there was a significant effect of location on growth of both traits with $p$-values $<0.01$. Height growth was significantly greater at the Rohwer site than either of the other two sites with an
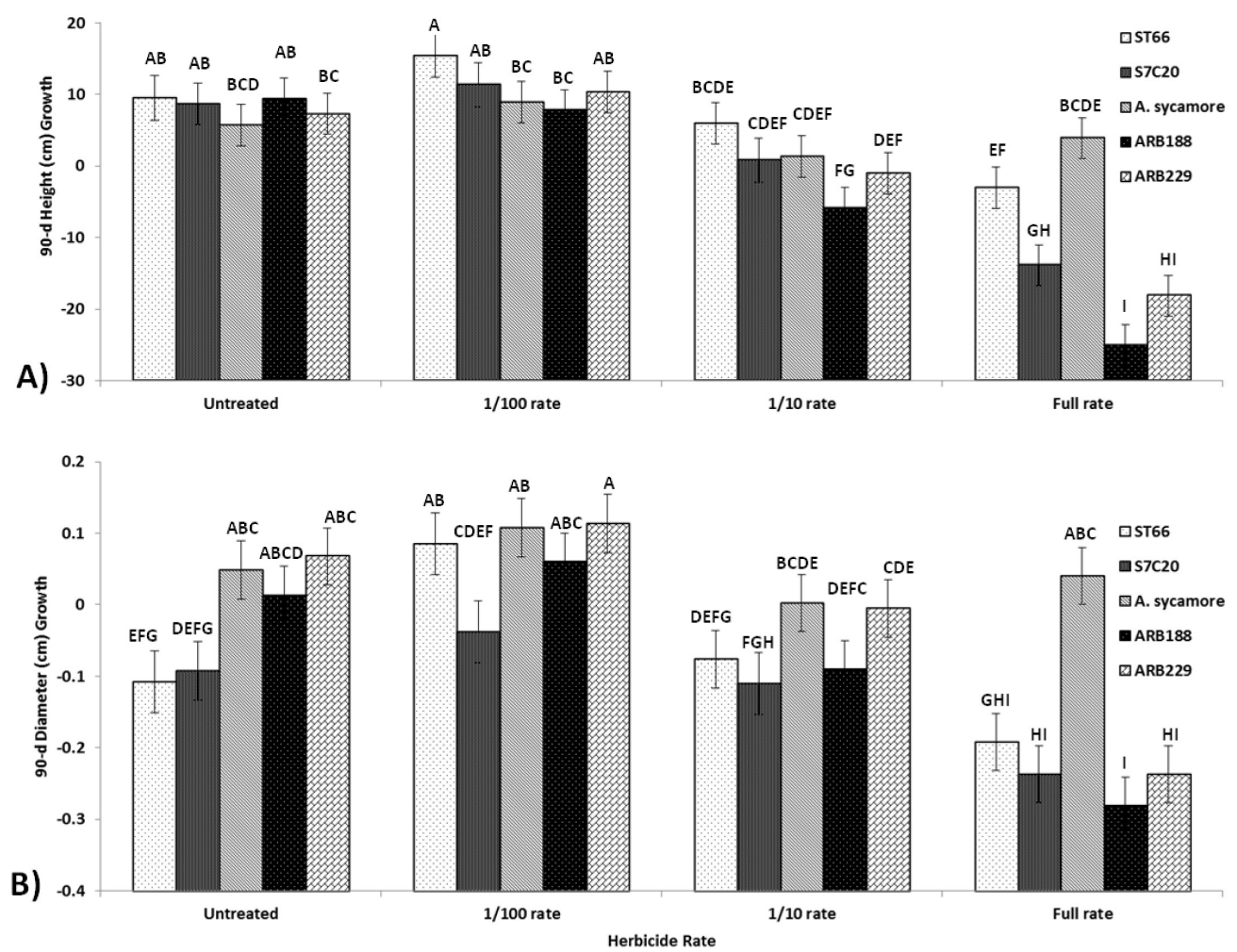

Figure 3 Growth of (A) height of the main stem and (B) ground line [American sycamore] or shoot base [four varieties of poplars] diameter across three rates of herbicide and a control after 90 days after treatment. 
average height growth of $33.6 \mathrm{~cm}$ greater than the combined average of Hope and Monticello sites. Diameter also exhibited better growth at the Rohwer site with an average of $0.12 \mathrm{~cm}$ growth compared to a decrease in diameter of $-0.1 \mathrm{~cm}$ at Monticello and $-0.17 \mathrm{~cm}$ at Hope. These decreases were due to dieback of the initial dominant stem and then resprouting. There was also significant interaction between stock type and herbicide treatment for height and diameter growth $(p$-values $<0.01)$. In the untreated trees, there was no significant difference among the five stock types (Figure 3a); while the two poplar clones ST-66 and S7C60 experienced a decrease in diameter due to dieback of the initial dominant stem resulting in a significantly smaller diameter stem than the other three stock types (Figure 3b). For diameter and height, there was a minor increase of $1.9 \mathrm{~cm}$ and $0.07 \mathrm{~cm}$ in growth at the 90 day measurement in the $1 / 100^{\text {th }}$ rate application compared to no herbicide across stock types. These increases were not significantly different among the treatment-by-stock combinations except for clone ST-66 diameter which had a 15 percent increase from the control to the $1 / 100^{\text {th }}$ rate treatment. A decrease of height and diameter for poplars was detected for the $1 / 10^{\text {th }}$ rate and full rate treatment. American sycamore had no significant differences across all treatments for either height or diameter.

\section{Photosynthetic changes across herbicide treatment}

Net photosynthesis was not significantly affected $(p=0.42)$ by an interaction of treatment and stock type nor by themselves individually ( $p=0.98$ and $p=0.64$, respectively). Photosynthesis trends were further explored through pairing with average treatment-by-stock growth data from the full 90-day period and the damage score from the same sampling day (60-day). Data were not paired with the individual tree data because several of the sampled trees did not survive through the completion of the study. There was distinct positive trend between photosynthesis and average damage score (Figure 4a) and negative trend between photosynthesis and average height change
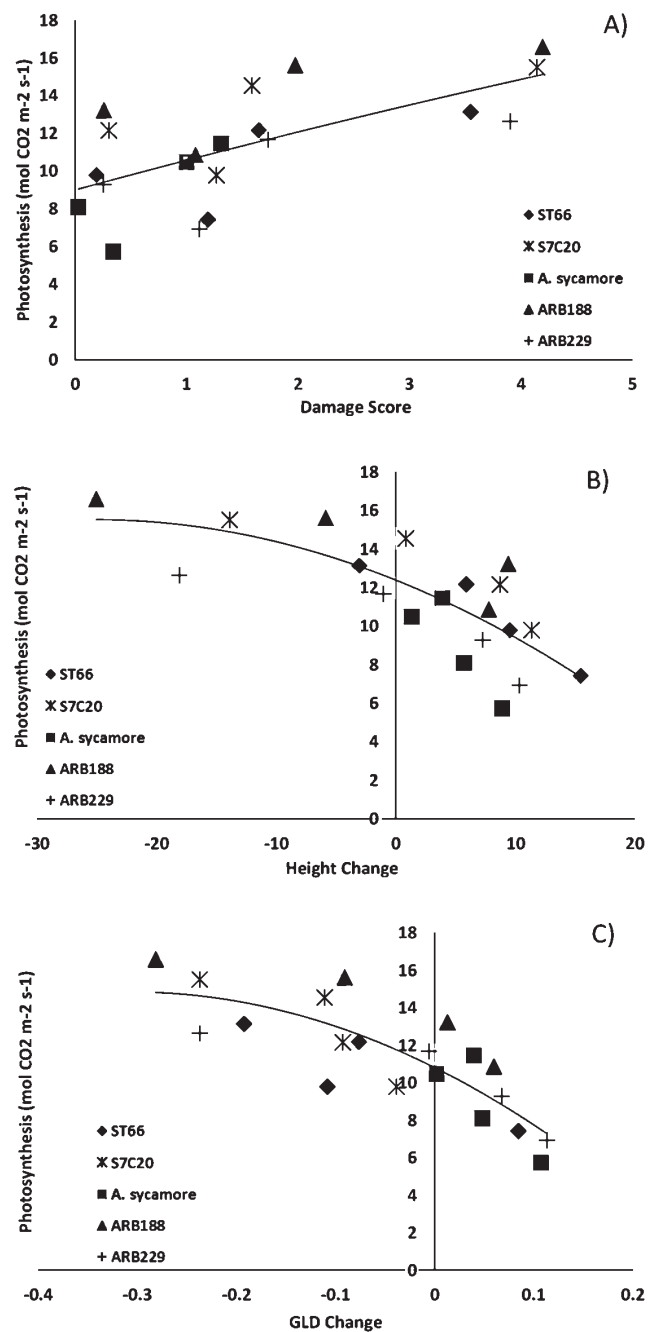

Figure 4 Net photosynthesis $\left(\mu \mathrm{mol} \mathrm{CO} 2 \mathrm{~m}^{-2} \mathrm{~s}^{-1}\right)$ of an intact leaf from an individual from each of the five stock type by four herbicide treatments at day-60. These values were plotted against the average (A) 60-d damage score, (B) height change $(\mathrm{cm})$, and (C) GLD change $(\mathrm{cm})$ where the change is the growth difference of each attribute from day 0 till day 90 . Trend lines indicate the directionality of data within in graph. 
(Figure 4b) and GLD change (Figure 4c). Average damage scores were then segregated into groups: no necrosis (i.e., 0,1) and necrosis or worse (i.e., 2 and greater). Trees showing necrosis at $60-\mathrm{d}$ included all poplars from the full herbicide rate and had an average net photosynthesis of $14.47 \mu \mathrm{mol} \mathrm{CO} \mathrm{m}^{-2} \mathrm{~s}^{-1}(n=$ 4$, s.d. $=1.88)$. There was a marked decrease in the net photosynthesis of less damaged trees with an average of $10.58 \mu \mathrm{mol} \mathrm{CO} \mathrm{m}^{-2} \mathrm{~s}^{-1}(n=$ $16, s . d .=2.72$ ). Segregation of data were also conducted among stock and treatment averages based on having a positive or negative (1) GLD change and (2) height change. There were six averages with height decreases, including all those with 60 -d scores greater than two. These groups that had a negative height change also had higher photosynthesis of $14.19 \mu \mathrm{mol} \mathrm{CO}_{2}$ $\mathrm{m}^{-2} \mathrm{~s}^{-1}(n=6$, s.d. $=1.97)$, while the positive height change groups had lower photosynthesis average of $10.14 \mu \mathrm{mol} \mathrm{CO} \mathrm{C}^{-2} \mathrm{~s}^{-1}(n=14$, s.d. $=2.51)$. GLD change was the most evenly segregated with nearly even number of averages having negative and positive values partially due to the previously referenced poor performance of clones S7C20 and ST-66. The average photosynthesis of the negative stock-bytreatments was $13.05 \mu \mathrm{mol} \mathrm{CO} \mathrm{m}^{-2} \mathrm{~s}^{-1}(n=11$; s.d. $=2.28)$ while positive combination average had photosynthesis of $9.28 \mu \mathrm{mol} \mathrm{CO} \mathrm{m}^{-2} \mathrm{~s}^{-1}(n$ $=9$, s.d. $=2.43$ ). Indeed, when photosynthesis reached an inflection point over $11.5 \mu \mathrm{mol} \mathrm{CO}$ $\mathrm{m}^{-2} \mathrm{~s}^{-1}$ (with the exception of two observations from the clones S7C20 and ST-66) there was either poor $60-\mathrm{d}$ score or negative average of height, diameter, or both.

\section{Discussion}

Use of dedicated SRWCs for biomass production continues to be a desirable source for meeting the renewable fuels standard 2007 goals which include the production of 75 billion liters of cellulosic ethanol or biofuel (Perlack \& Stokes 2011). To meet the mandate, many lands that are under-producing in agri- culture are being targeted for SRWC plantation establishment but are usually surrounded by a landscape of high-productivity and intensely managed agriculture lands. Thus, a tree used as a SRWC must both be quick growing, but also resilient to any interactions with intensive agriculture practices.

Seedlings of American sycamore and Arborgen cuttings performed very well with greater than 90 percent survival in untreated plots. The clones ST-66 and S7C20 performed very poorly overall, even in the untreated areas. Poor survival may be due to later than optimal planting time for these two clones. S7C20 was reported to have a drastic decline of survival when planted in March or April with a consistent survivability less than 45 percent (Singh et al. 2005), whereas Coyle et al. (2003) reported ST-66 planted the first week of February (2000) had 74 percent survival and S7C20 having 65 percent or greater survival when planted in January or February (1997-1999) (Singh et al. 2005).

The poor performance of these two particular clones appeared late in the study as indicated by the damage scores. At the 60-day observation, ST-66 and S7C20 were both performing similarly in untreated plots as the other three stocks. In the 60 to 90 day period, these two clones exhibited damage probably caused by water stress. Still, surviving trees for all stock types in the untreated plot had positive height growth after 90-days, averaging $8.74 \mathrm{~cm}(s . d .=$ $2.95 \mathrm{~cm}$ ). However, only ARB229 was statistically different from other studies in regards to height growth (i.e., ARB229 was significantly less than ST-66 and S7C20). Conversely, only clone ARB229 had an increase in GLD after 90 days in the untreated area of $0.07 \mathrm{~cm}(s . d .=$ 0.03 ). The nearly ubiquitous decreases or stagnation of GLD for the other stocks is mostly due to early dieback of the dominant stem and replacement by another stem or initial allocation of resources to height growth.

Quinclorac had a notable effect on trees in this study in regards to repeated damage scores and end of study survival and growth measure- 
ments. Notably for all poplars, there was a definite increase in damage in both the $1 / 100^{\text {th }}$ and $1 / 10^{\text {th }}$ rate applications, mimicking incidental drift, but did not cause catastrophic damage. The full rate did result in extreme damage with near complete defoliation or mortality as early as 30 days (Figure 2a). This was also reflected in the final survival percentages in which major decreases were especially evident in the better overall preforming clones ARB188 and ARB229 (Figure 1). These major increases in damage scores, negative impacts on growth, and mortality at the full herbicide rate would be the result most likely in practice from direct spraying. Notably among the stock types was the apparent resistance of American sycamore to quinclorac, even at a full rate. Not only did American sycamore survive but seedlings generally maintained growth in height and GLD under a full rate as compared with untreated seedlings.

Photosynthetic rate measurements were limited in that they were only taken on a single site and time point. Still, the measurements showed a distinct trend when compared with growth attributes over 90 days and the damage score assessment. Across all stock types there was a positive trend between damage score and photosynthetic rate, while there were negative trends between photosynthesis and both height and GLD growth. Stock and herbicide rates that resulted in increased damage scores were plants that had by definition more leaf chlorosis, necrosis, and other morphological abnormalities (Table 1) which may be expected to decrease a plant's potential photosynthetic rate. However, remaining leaves on damaged plants have been well documented to have higher photosynthetic rates. One-year old Populus maximowiczii $x$ nigra trees that were decapitated and allowed to reshoot had over 50 percent greater photosynthetic rate and a 37 percent increase in leaf dry weight compared to unpruned trees (Tschaplinski \& Blake 1995). Pruning of young black alder (Alnus glutinosa) led to lower transpiration rates for 48 days post pruning and net assimilation rate increase for the first 30 days as pruning intensity increased (Singh \& Thompson 1995). Similarly, removal of upper leaves and leaf laminae in silver birch (Betula pendula) saplings led to increased photosynthetic rates (Ovaska et al. 1992). The increasing photosynthetic rates in silver birch was attributed to alleviated competitive status among the remaining leaves. Still, these increases in remaining leaves or new, post-herbicide leaves correspond to depletion of metabolites including sucrose and galactose in the stems (Tschaplinski \& Blake 1994) and a reduction of carbohydrates and starches in both the lower stem and roots (Tschaplinski \& Blake 1995). Potentially, minor defoliation and stem dieback events may not lead to losses in overall biomass due to the rapid regrowth and improved water status due to less transpiration in the reduced leaf area (Seastedt et al. 1983; Singh \& Thompson 1995). However under field conditions where water stress increases during drier summer months following exposure to quinclorac, trees are at a great risk of reserve depletion that leads to decreases in biomass and increases in mortality.

With a low level of quinclorac exposure there was a slight increases in leaf photosynthetic rate. This, coupled with a possible minimal drain of root and stem reserves, may have led to a small increase in growth in the $1 / 100^{\text {th }}$ rate treatment. Though there was not a significant increase in growth traits from the control, after 90 days there was a $2.5 \mathrm{~cm}$ height and $0.08 \mathrm{~cm}$ GLD increase with a slight increase in observed damage and virtually no effect on survival. Only after exposure to at least the $1 / 10^{\text {th }}$ rate, did negative effects become evident. A beneficial effect from a herbicide, hormesis, is not without precedent and has been observed in the common herbicide glyphosate (Cedergreen 2008a,b; Velini et al. 2008) and is certainly a possibility for a synthetic auxin herbicide such as quinclorac. Indeed, other synthetic auxin herbicides have been shown to increase leaf area and biomass growth when applied at low dosage. When cotton plants were treated with $2 \mu \mathrm{g} / \mathrm{L}$ of $2,4-\mathrm{D}$, 
leaf area increased by 28 percent over controls and dry weight increased 36 percent (Allender et al. 1997). Synthetic auxins MCPA and Mecoprop have both been demonstrated to have some small hormesis activity in an array of plant species (Cedergreen et al. 2007).

\section{Conclusions}

Hardwood plantings, especially for biomass production, require careful consideration of species-site relationships. In the past, the selection of a species has been made based on ecological concerns. However, due to locating many plantings near production agriculture fields, species must be assessed not only for ecological suitability to the natural environment but also on how they fit in the agro-landscape. American sycamore is clearly superior to resistance of the common rice herbicide quinclorac. Within the four test poplar clones, there was variability in response with the newer Arborgen clones growing better in the drift rates (i.e., $1 / 10^{\text {th }}$ and $1 / 100^{\text {th }}$ rate) while no poplar clone did well under direct herbicide exposure. In conclusion, American sycamore growth rates and ease of propagation may not meet the standards set by the best poplar clones; however, the risk of growth inhibition and/or death due to this herbicide is minimal and American sycamore should be given deference when there is potential drift from quinclorac.

\section{Acknowledgements}

This project was conducted in part due to efforts of graduate students at the University of Arkansas at Monticello included Nicholas Mustoe and Shakuntala Sharma. These students helped with the planting and measurement of the trees. Cuttings and seedlings were provided by Arborgen $\subset$ and Mississippi State University.

\section{References}

Allender, W.J., G.C. Cresswell, J. Kaldor, and I.R. Kennedy, 1997. Effect of lithium and lanthanum on herbicide induced hormesis in hydroponically-grown cotton and corn. Journal of Plant Nutrition 20(1):81-95. DOI: 10.1080/01904169709365235

Brown, C.L., 1976. Forests as energy sources in the 2000: what man can imagin, man can do. Journal of Forestry 74(1):7-12.

Cedergreen, N., 2008a. Herbicides can stimulate plant growth. Weed Research 48(5):429-438. DOI: 10.1111/j.1365-3180.2008.00646.x

Cedergreen, N., 2008b. Is the growth stimulation by low doses of glyphosate sustained over time? Environmental Pollution 156(3):1099-1104. DOI: 10.1016/j.envpol.2008.04.016

Cedergreen, N., J.C. Streibig, P. Kudsk, S.K. Mathiassen, and S.O. Duke, 2007. The occurrence of hormesis in plants and algae. Dose-response 5(2):150-162. DOI: 10.2203/dose-response.06-008.Cedergreen

Coyle, D.R., J. Blake, K. Britton, M. Buford, R.G. Campbell, J. Cox, B. Cregg, D. Daniels, M. Jacobson, K. Johnsen, T. McDonald, K. McLeod, E. Nelson, D. Robison, R. Rummer, F. Sanchez, J. Stanturf, B. Stokes, C. Trettin, J. Tuskan, L. Wright, and S. Wullschleger, 2003. Production of short-rotation woody crops grown with a range of nutrient and water availability: Establishment report and first-year responses. USDA Forest Service, Savannah River, New Ellenton, SC. Medium: ED, 26 p.

Davis, A.A., and C.C. Trettin, 2006. Sycamore and sweetgum plantation productivity on former agricultural land in South Carolina. Biomass and Bioenergy 30(89):769-777. DOI: 10.1016/j.biombioe.2005.08.001

Dickmann, D.I., J.G. Isebrands, J.E. Eckenwalder, and R. J.E., 2001. Poplar culture in North America. NRC Research Press, Ontario, Canada. 397 p.

Dosskey, M.G., G. Bentrup, and M. Schoeneberger, 2012. A role for agroforestry in forest restoration in the Lower Mississippi Alluvial Valley. Journal of Forestry 110(1):48-55. DOI: 10.5849/jof.10-061

Fipke, M., and R. Vidal, 2016. Integrative theory of the mode of action of quinclorac: literature review. Planta Daninha 34(2):393-402. DOI: 10.1590/S010083582016340200020

Freemark, K., and C. Boutin, 1995. Impacts of agricultural herbicide use on terrestrial wildlife in temperate landscapes: a review with special reference to North America. Agriculture, Ecosystems \& Environment 52(2):6791. DOI: 10.1016/0167-8809(94)00534-L

Graham, R.L., 1994. An analysis of the potential land base for energy crops in the conterminous United States. Biomass and Bioenergy 6(3):175-189. DOI: 10.1016/09619534(94)90074-4

Grossmann, K., 2010. Auxin herbicides: current status of mechanism and mode of action. Pest Management Science 66(2):113-120. 
Johnson, J.M., M.D. Coleman, R. Gesch, A. Jaradat, R. Mitchell, D. Reicosky, and W. Wilhelm, 2007. Biomass-bioenergy crops in the United States: A changing paradigm. The Americas Journal of Plant Science and Biotechnology 1:1-28.

Kline, K.L., and M.D. Coleman, 2010. Woody energy crops in the southeastern United States: two centuries of practitioner experience. Biomass and Bioenergy 34(12):1655-1666. DOI: 10.1016/j.biombioe.2010.05.005

Laurance, W.F., P. Delamônica, S.G. Laurance, H.L. Vasconcelos, and T.E. Lovejoy, 2000. Conservation: rainforest fragmentation kills big trees. Nature 404(6780):836-836. DOI: 10.1038/35009032

Meilan, R., K.-H. Han, M. CaiPing, R.R. James, J.A. Eaton, B.J. Stanton, E. Hoien, R. Crockett, and S.H. Strauss, 2000. Development of glyphosate-tolerant hybrid cotton woods. Tappi journal 83(1).

Merz, R.W., 1965. American sycamore (Platanus occidentalis L.). In: Fowells, H.A. (ed.), Silvics of forest trees of the United States. U.S. Department of Agriculture, Washington, D.C., pp. 489-495.

Miller, D.R., T.E. Stoughton, 2000. Response of spray drift from aerial applications at a forest edge to atmospheric stability. Agricultural and Forest Meteorology 100(1):49-58. DOI: 10.1016/S0168-1923(99)00084-2

Milliken, G.A., and D.E. Johnson, 1989. Analysis of messy data vol. 2: Nonreplicated experiments. Chapman \& Hall, Boca Raton, 199 p.

Newcombe, G., and M. Ostry, 2001. Recessive resistance to Septoria stem canker of hybrid poplar. Phytopathology 91(11):1081-1084. DOI: 10.1094/PHYTO.2001.91.11.1081

Norsworthy, J.K., N.R. Burgos, R.C. Scott, and K.L. Smith, 2007. Consultant perspectives on weed management needs in Arkansas Rice. Weed Technology 21(3):832-839. DOI: 10.1614/WT-06-203.1

Ovaska, J., M. Wall, and P. Mutikainen, 1992. Changes in leaf gas exchange properties of cloned Betula pendula saplings after partial defoliation. Journal of Experimental Botany 43(10):1301-1307. DOI: 10.1093/ $\mathrm{jxb} / 43.10 .1301$

Perlack, R.D., and B.J. Stokes, 2011. US billion-ton update: biomass supply for a bioenergy and bioproducts industry. Laboratory, O.R.N. (ed.), Oak Ridge, TN.

Rousseau, R.J., J.P. Adams, and D.W. Wilkerson, 2013. Nine-year performance of a variety of Populus taxa on an upland site in western Kentucky. P. 299-305 in Biennial Southern Silviculture Reseach Conference, Guildin, J.M. (ed.). U.S. Department of Agriculture, Forest Service, Southern Research Station, Hot Springs, AR.

Rudel, T.K., O.T. Coomes, E. Moran, F. Achard, A. Angelsen, J. Xu, and E. Lambin, 2005. Forest transitions: towards a global understanding of land use change. Global Environmental Change 15(1):23-31. DOI: 10.1016/j.gloenvcha.2004.11.001

Seastedt, T., D. Crossley Jr, and W. Hargrove, 1983. The effects of low-level consumption by canopy arthropods on the growth and nutrient dynamics of black locust and red maple trees in the southern Appalachians. Ecology:1040-1048. DOI: 10.2307/1937812

Singh, K., O. Rao, and B. Rana, 2005. Growth and biomass performance of S7C20 clone of Populus deltoides Marsh as influenced by plantation period. Indian Journal of Agroforestry 7(2):40-45.

Singh, K., and F. Thompson, 1995. Effect of lopping on water potential, transpiration, regrowth, 14C-photosynthate distribution and biomass production in Alnus glutinosa. Tree Physiology 15(3):197-202. DOI: 10.1093/ treephys/15.3.197

Autho. 1999. Thirty years of short-rotation hardwoods research. In: Haywood, J.D. (ed.), Biennial Southern Silvicultural Research Conference. U.S. Department of Agriculture, Forest Service, Southern Research Station, pp. 63-65.

Taylor, J.L., 2001. Populus deltoides. Fire Effects Information System. U.S. Department of Agriculture, Forest Service, Rocky Mountain Research Station, Fire Sciences Laboratory.

Tschaplinski, T.J., and T.J. Blake, 1994. Carbohydrate mobilization following shoot defoliation and decapitation in hybrid poplar. Tree Physiology 14(2):141-151. DOI: 10.1093/treephys/14.2.141

Tschaplinski, T.J., and T.J. Blake, 1995. Growth and carbohydrate status of coppice shoots of hybrid poplar following shoot pruning. Tree Physiology 15(5):333-338. DOI: 10.1093/treephys/15.5.333

Velini, E.D., E. Alves, M.C. Godoy, D.K. Meschede, R.T. Souza, and S.O. Duke, 2008. Glyphosate applied at low doses can stimulate plant growth. Pest Management Science 64(4):489-496. DOI: 10.1002/ps. 1562

Williams, W., G. Wehtje, and R.H. Walker, 2004. Quinclorac: soil behavior and foliar vs. root absorption by torpedograss (Panicum repens) 1. Weed technology 18(3):626-633. DOI: 10.1614/WT-03-109R

Xu, J., B. Lv, Q. Wang, J. Li, and L. Dong, 2013. A resistance mechanism dependent upon the inhibition of ethylene biosynthesis. Pest Management Science 69(12):1407-1414. DOI: 10.1002/ps.3524

Zamora, D.S., K.G. Apostol, W.E. Berguson, T.A. Volk, J. Wright, and E.J. Ogdahl, 2015. Short rotation woody crops biomass production. In: Jose, S., and T. Bhaskar (eds.), Biomass and biofuels: Advanced Biorefineries for Sustainable Production and Distribution. CRC Press, Boca Raton. 